\title{
A Conceptual Research Model for Investigating the Impact of Online Teacherpreneurship Education on Students' Teacherpreneurial Competencies and Intentions in Preservice Teacher Education
}

\author{
Olusiji Adebola Lasekan \\ Universidad Católica de Temuco, Temuco, Chile \\ https:// orcid.org/0000-0002-4244-4852 \\ Reyaz Malik \\ Central University of Karnataka, Kalaburagi, India \\ https://orcid.org/0000-0003-2443-5108 \\ Claudia Méndez Alarcon \\ Universidad Católica del Maule, Talca, Chile \\ https://orcid.org/0000-0002-6327-934X
}

\begin{abstract}
This article seeks to develop a research model that can be employed to study the impact of online teacherpreneurship education on students' teacherpreneurial competence and intention as well as employability. Based on the redefinition of the role of online teacherpreneur as an online private tutor, instructional designer, entrepreneur, and teacher leader, a qualitative literature review of competencies for these roles was conducted. We merged the identified competencies according to conceptual similarities. Our result is an online teacherpreneurship competency adopted to formulate a research model which is a customized measuring instrument for investigating the effect of online teacherpreneurship training on preservice teachers' teacherpreneurial competencies and intentions. This finding has important implications for developing a template for students, policymakers, and teacher educators needed to create online teacherpreneurship courses, curricula, and evaluations.
\end{abstract}

Keywords: online teacherpreneurship; entrepreneurial intention; teacher leadership; instructional designing; online private tutor

\section{Introduction}

Berry, Byrd and Wieder (2013) are among the first to incorporate a concept of teacherpreneurship into academic writing. They describe teacherpreneurs as teachers who cultivate and 'sell' their pedagogical talents while at the same time seeking creative solutions to the challenges of the education sector. The increasing rate of precarious employment in the education sector is a critical factor 
compelling teachers to engage in this practice (Lasekan, Moraga \& Galvez, 2020). According to Palmer (2017), a teacherpreneur is a creative teacher who is both an educator and an entrepreneur, working a flexible schedule to supplement his or her income by creating and developing teaching and learning products. In sum, teacherpreneurship can simultaneously enhance teachers' financial freedom while fostering the quality of teaching and innovation in education (Syam, 2019). This capability strengthens its pivotal importance in entrepreneurship education studies.

Due to easy access to the internet in the past two decades, online education has proliferated in numerous higher education institutions (Tao \& Yeh, 2008). The current COVID-19 ravaging the globe has compelled nearly all educational institutions to adopt this teaching mode. Though several studies conducted in different contexts have reported successful implementation of online education with its positive impact on students learning outcomes (Allo, 2020: Tartavulea et al., 2020), there are numerous reports on challenges hampering the successful implementation of online teaching (Rajab, Gazal \& Alkattan, 2020: Farooq, Rathore \& Mansoor, 2020). Nevertheless, it has been predicted that many higher educational institutions will continue to offer online education after this postpandemic era because it provides flexible, convenient, and interactive methods of instruction to students (Goh \& Sandars, 2020). Also, considering the affinity spaces such as Instagram and Facebook, where the increasing number of teachers are sharing professional experience and instructional material for financial gain (Carpenter et al., 2020). Thus, it can be argued that this transition and the new phenomenon will cause more teachers to embrace online teacherpreneurship. Though, Shelton and Archambault (2018) limit the scope of online teacherpreneurs to teachers who market their original classroom materials and ideas with colleagues and policymakers on social media such as Instagram and Pinterest. However, considering the increasing growth of online private tutoring business (Bray, 2006). It can be contended that online private tutoring should also be one of the core competencies of online teacherpreneurship. Thus, it is crucial to redefine the concept and competence of online teacherpreneurship and advocate for its inclusion in the preservice teacher education curriculum. This can be done by developing a model that assesses its education impact on students' learning outcomes.

In entrepreneurship education, entrepreneurship competence and entrepreneurship intention are the two strong predictors to determine a successful entrepreneurship program (Sánchez, 2013). Both concepts can also be used to assess the impact of online teacherpreneurship education. Therefore, this study aims to conceptualize a research model that can be used to study the effect of online teacherpreneurship education on students' perceived teacherpreneural competences, teacherpreneural intentions, and perceived employability. After the introduction, we present a literature review. The methodology follows them. Based on the findings, we proposed an online teacherpreneurship competence construct. We adopted it to conceptualize the research model to study the impact of online teacherpreneurship education on teacherpreneural competencies, intention, and perceived employability in preservice teacher education. 


\section{Literature Review}

One of the ways every government is promoting entrepreneurship is through its education. As a result of this, entrepreneurship education is becoming popular in several higher educational institutions (Hattab, 2014: Al Mamun, Nawi \& Shamsudin, 2016). In the European Union (EU) countries, the education is critical to the socio-economic development of the continent (Bacigalupo et al., 2016). In Chile's case, the government believes that the commercial success of the smallmedium firms, which is vital to economic growth, depends on the successful implementation of entrepreneurship education in the national curriculum (Maldifassi, 2001). Entrepreneurship education is concerned with learning for, through, and about entrepreneurship (Gibb, 2005). For this reason, it is claimed that entrepreneurship education should be regarded as both a learning method as well as learning material (Remes, 2001). Albornoz (2013) identified two teaching goals of every entrepreneurship training. These goals include teaching how to start a successful business and teaching to develop students' entrepreneurial skills. Considering the subjectivity nature of entrepreneurship whose training is extending beyond major business discipline to non-business courses such as medical programs (Li, 2017), preservice teacher education programs (Deveci \& Seikkula-Leino, 2018), engineering programs (Duval-Couetil, Reed-Rhoads \& Haghighi, 2012), and postgraduate programs (Rae \& Woodier-Harris, 2012), several scholars are now advocating for teaching goals that focus only on the enhancement of entrepreneurship mindset of students in all disciplines (Brand, Wakkee \& Van der Veen, 2007: Martin \& Iucu, 2014). The aim is to connect the worlds of education and work by improving students' ability to turn ideas into action, which add benefit value for someone other than oneself (Bacigalupo et al., 2016). Thus, it will be interesting to explore the impact of online teacherpreneurship as a sub-dimension of entrepreneurship education in preservice teacher education programs.

Entrepreneurship Competence (EC) and Entrepreneurship Intention (EI) are the two key predictors of successful entrepreneurship programs. While EC is defined as the general skills of an entrepreneur to carry out the job (Man et al., 2002), EI, which is grounded on a theory of planned behaviour, is defined as the vocational decision process undergoes by an individual to join an occupation as a salaried earner or entrepreneur (Katz, 1992). Numerous studies on Entrepreneurship Education (EE) have used these two concepts to evaluate entrepreneurship programs (Sanchez, 2013: Hattab, 2014). A pretest-posttest quasi-experimental design to assess the impact of entrepreneurship training on the students' EC revealed that the students' proactivity, risk-taking, self-efficacy and selfemployment motive are fostered after the training (Sanchez, 2013).

A similar study to measure the impact of EE on the entrepreneurial intention among Egyptian students established a positive relationship between EE and EI (Hattab, 2014). Also, specific entrepreneurship competencies have been identified to be the driver of EI. In a study conducted among students of Faculty of Entrepreneurship and Business, Universiti Malaysia Kelantan, competencies such as the ability to identify income-generating opportunities, entrepreneurial skills, creativity, and information-seeking skill have a higher impact on EI of students 
(Al Mamun, Nawi \& Shamsudin 2016). In addition, considering that some EE programs are strictly designed to foster employability, which is 'a collection of skills, knowledge and personal qualities that make an individual more likely to safe and successful in their chosen profession after graduation (Moreland, 2006), a high self-perception of employability can also be used as a strong predictor of a good entrepreneurship program. While a study has established a positive impact of EE on the employability skills of British undergraduate students (O'Leary, 2012), another study reported similar positive results among Irish and Croatia students (Robinson, 2018). The literature gap is a work on the construction of online teacherpreneurship competence to assess the impact of its education.

Teachers' professionalism and qualifications are bound and designed to change according to global needs (Whitty, 2000). Therefore, teachers' competence has to adjust to the curriculum change, work efficiency, and systematic teacher assessment (Bancotovska, 2015) to improve the quality of teaching needed in modern education (Syam \& Arifin, 2018). Trilling \& Fadel (2009) explained that in the 21st century, one has to master the three core skills, i.e., life and career skills, innovation skills, and information media and technology skills (Ashari, Syam \& Budiman, 2017). Therefore, it is essential to foster these skills among preservice teachers to adjust teacher professionalism to 21st-century challenges. Several preservice teacher education programs in different contexts have started implementing teacherpreneurship education for several reasons. In Indonesia, the education was used to foster teachers' professionalism by developing their creativity and effectiveness (Sofyan \& Efendi, 2017). In Pakistan's case, it was adopted to provide female teachers with knowledge and skills to enhance their competence to launch and sustain their businesses for their socio-economic wellbeing (Qureshi, Khanam \& Aziz, 2018). In Europe, EIPTE is an innovative Erasmus ongoing project that aims at stimulating the entrepreneurial mindset of preservice teachers (Arruti \& Paños-Castro, 2020). Despite the successful implementation in different contexts, there is yet to be a study on implementing online teacherpreneurship education.

Works on the concept of teacherpreneurship have focused on defining the characteristics of teacherpreneurs. A good example are tutors who teach students but still have space and time to nurse and implement their ideas (Berry, Byrd \& Wieder, 2013). Arruti \& Paños-Castro (2019, p. 20) describe them as professionals who are placing students at the center of their work, pursuing personal and professional development, exhibit leadership skill, adopting active methodologies, daring to break the pre-established rules from time to time, and established a significant network of a professional network. The third important characteristic of teacherpreneurs are those that market their teaching skills either as face to face or online private tutors, which is more prominent in nonmainstream EFL education (Torrengiani, 2020). The private tuition industry's global growth has increased drastically in different countries over the years (Baker \& Le Tendre, 2005). For example, Lasekan, Moraga and Galvez (2020) reported a socio-demographic profile of the high volume of English private tutors in Chile. Similarly, teaching opportunities outside mainstream education have been revealed in the discipline of physical education (PE). (Adeogu \& Adeyeye, 2012). 
The authors claim that PE teachers can express their entrepreneurial productivity in several broad areas such as Club Fitness Instructor, Clinical Exercise Physiologist, and sports teacher. To maximize teachers' potential in the fitness industry, the experts stress the importance of entrepreneurship education for prospective physical education teachers. In sum, considering the dynamism and needs of global education, teacherpreneurs can offer their services as private tutors, content developers, and consultants in their respective disciplines. Thus, it is essential to conduct a study on the role of teacherpreneur as a private tutor in both mainstream and non-mainstream of education.

By 2017, the discussion on teacherpreneurship has begun to metamorphose into online teacherpreneurship. Scholars reported different educational services that online teacherpreneurs could offer their clients (Shelton \& Archambault, 2018; Carpenter et al., 2020). First, teachers focus on creating and selling teaching material and resources for other teachers to use on a popular online educational marketplace such as TeachersPayTeachers.com and Pinterest (Shelton \& Archambault, 2018). The study attributed the continuous increase in the practice among teachers to the emergence and growth of the online educational marketplace industry, such as TeachersPayTeachers.com, Pinterest, TES, Amazon Inspire, and Houghton Mifflin, where teachers sell their instructional material to other teachers (Shelton, 2018). Secondly, the low salary income of most teachers (Allegretto \& Mishel, 2019). Thus, many teachers use this alternative way of selling authentic material to augment their income (Shelton \& Archambault, 2019). Works on online teacherpreneurship are still gaining momentum. A recent study explored how teachers practice online teacherpreneurship on Instagram (Carpenter et al., 2020). The gap in the literature is a study on the competencies that an online teacherpreneur needs to possess.

Against this background, we present the key research questions of this study as follows:

1. Based on a broad range of literature, what competencies do future online teacherpreneurs need to acquire?

2. What is the conceptual research model to study the effect of online teacherpreneurship education on online teacherpreneural competencies and intentions?

\section{Methodology}

In reviewing the literature, no study was found on developing a model that assesses the impact of online teacherpreneurship education on Students' teacherpreneurial competencies and intentions in preservice teacher education. Thus, this study set out to conceptualize a research model that can be used to study the impact of online teacherpreneurship education on students' perceived teacherpreneural competences, teacherpreneural intentions, and perceived employability.

\section{Research Design}

The research design is inspired by Foucrier \& Wiek (2019) and Draksler \& Širec (2018) on the conceptual research model of sustainable entrepreneurship 
competence and entrepreneurship competence, respectively. The research is divided into three sections (Figure 1).

I. Qualitative Literature Review of Tasks: Peer-reviewed literature was identified, selected, and evaluated. Reference work has been established via Google Scholar (the broadest database for academic studies). Also, we verified with other databases and no additional sources of interest was found. Studies were identified through Google using the terms: "Teacherprenuer", "Teacherpreneurship", "online teacherpreneur", "online teacherpreneurship", and "Entrepreneurship in Teachers education". The most relevant sources were selected. Criteria such as works that precisely defined the term, published in or after 2010, and works derived the synthesis of existing literature was adopted. The final collection contained the following peer-reviewed studies: Van Dam, Schipper and Runhaar (2010). Buckley and Nzembayie (2016). Berry (2011), Bingham (2017), Qureshi, Khanam and Aziz, (2018), Shelton and Archambault (2019), Shelton (2018), Ni' mah, Siswandari and Indrawati (2018), Aryanto, Ariffiando and Andriani (2017), Shelton and Archambault, (2018), Feriady and Santoso, (2020), Keyhani and Kim (2020), Arruti and Panos-Castro (2020). Firstly, each source was then analyzed as teacherpreneurial tasks.

II. Qualitative Literature Review of Competencies: Concerning the newly conceptualized roles of online teacherpreneur, every literature was analyzed. Thus, the result is clustered into the four competencies (online teaching, instructional designing, teacher leadership, and entrepreneurship competence) needed to perform online teacherpreneur.

The first cluster includes entrepreneurship competencies. It is focused on the role of online teacherpreneurs who are in-service teachers and possess entrepreneurial skills and used them directly relevant to their classrooms or the education system they have served (Oplatka, 2014). The second cluster covers teacher leadership competencies because online teacherpreneur are leaders who can virtually influence a broad audience of teachers and students who adopt their instructional materials and ideas for practices (Shelton, 2018). The third cluster (online teaching competencies) was included because their practice is expected to offer online private tutoring services (Torregiani, 2020). The final cluster (instructional designing competencies), which is accounted for in literature, involves creating and selling instructional material on different online platforms (Shelton \& Archambault, 2018). Results were eventually scanned for redundancies, cleanedups, and synthesis.

III. Framework synthesis: A limited collection of criteria was used to create the new competency structure which can be used to design curriculum and course for online teacherpreneurship programs. The design protocol adopted by Foucrier \& Wiek (2019) include:

(a) Definition and standardization of competencies from the literature in order to prevent generic definitions or redundancies

(b) Linking gaps in the literature (for example, missing or unestablished roles or competencies); 
(c) the use of online teacherpreneurial practice-orientation by mapping out basic functions and competencies to prevent "laundry-listing" skills;

(d) The use of core competencies in different studies as a guide to connect the ongoing debate of competency in various fields.

For the impact of online teacherpreneurship education, we developed a simple conceptual research model using insights from entrepreneurship education studies (Draksler \& Širec, 2018), .and from our literature review. The impact is modeled through the assessment of perceived teacherpreneurial competency, intention, and employability.

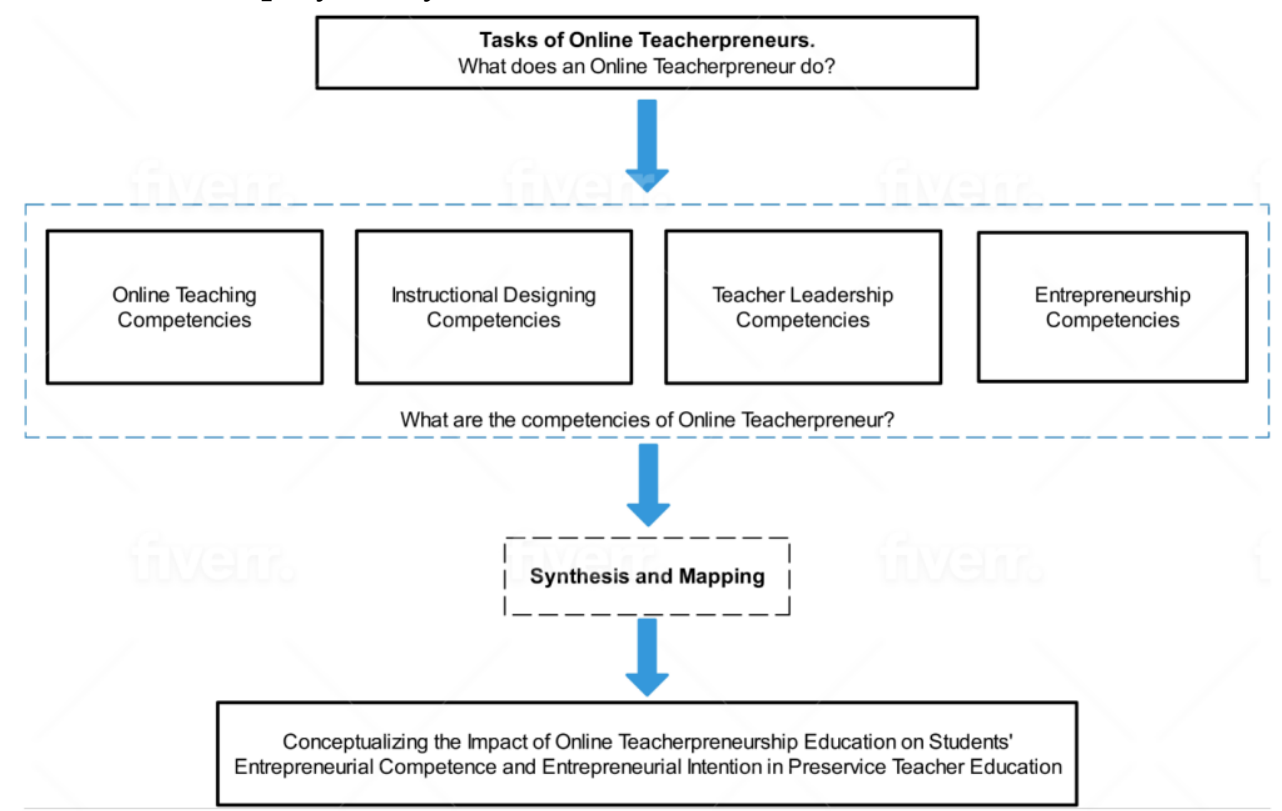

Figure 1: Overview of research design adapted from "A process-oriented framework of competencies for sustainability entrepreneurship" by Foucrier, T., \& Wiek, A. 2019. Sustainability, p.4

\section{Results}

The synthesis of competencies for online teacherpreneurship commences with a thorough view at the roles that online teacherpreneurs supposed to perform and the related competencies needed to perform such duties. This is the basis for the new competency structure for online teacherpreneurship education and its impact on students' learning outcomes.

Tasks-What does online teacherpreneur do?

Developing online teacherpreneurship competence is essential to redefine the tasks of online teacherpreneurs by considering how different scholars have described the roles of both teacherpreneurs and online teacherpreneurs. Teacherpreneurs are professionals who have a great passion for teaching, a positive attitude, and a strong ability to inspire others (Arruti \& Paños-Castro, 2019). Berry (2011) regarded teacherpreneurs as marketers and professionals who are paid to spread their ideas and content as virtual mentors, teacher educators, community leaders, and policy as well as action researchers. They are described as teachers full of ideas concerned with their students, family, and community and know how to do all the roles (Ni' mah et al., 2018). Teachers who can actualize the potential of entrepreneurs and are expected to be much more productive 
professionals, able to create opportunities, like to challenge, independent, and have an unyielding spirit (Aryanto, Ariffiando \& Andriani 2017). On the other hand, online teacherpreneurs are current and former K-12 classroom teachers. They engage in educational entrepreneurship, selling their original classroom materials in virtual marketplaces such as TpT, TES, Teachers Notebook, and Houghton Mifflin Harcourt Marketplace (Buckley \& Nzembayie, 2016). They are also described as experienced teachers who gain professional authority and influence as a teacher leader (Holland, Eckert \& Allen, 2014). Lastly, Shelton (2018) describe them as professional with innovative teaching skills, entrepreneurship mindset, online technology skill, as well as teacher leadership skills. In light of these definitions, we redefine online teacherpreneurs as teachers with an entrepreneurial mindset who offer virtual private tutoring service to students, develop and sell their instructional material to other teachers on the internet, and provide online mentoring and leadership service to other teachers, school management and educational policymakers (see figure 2).

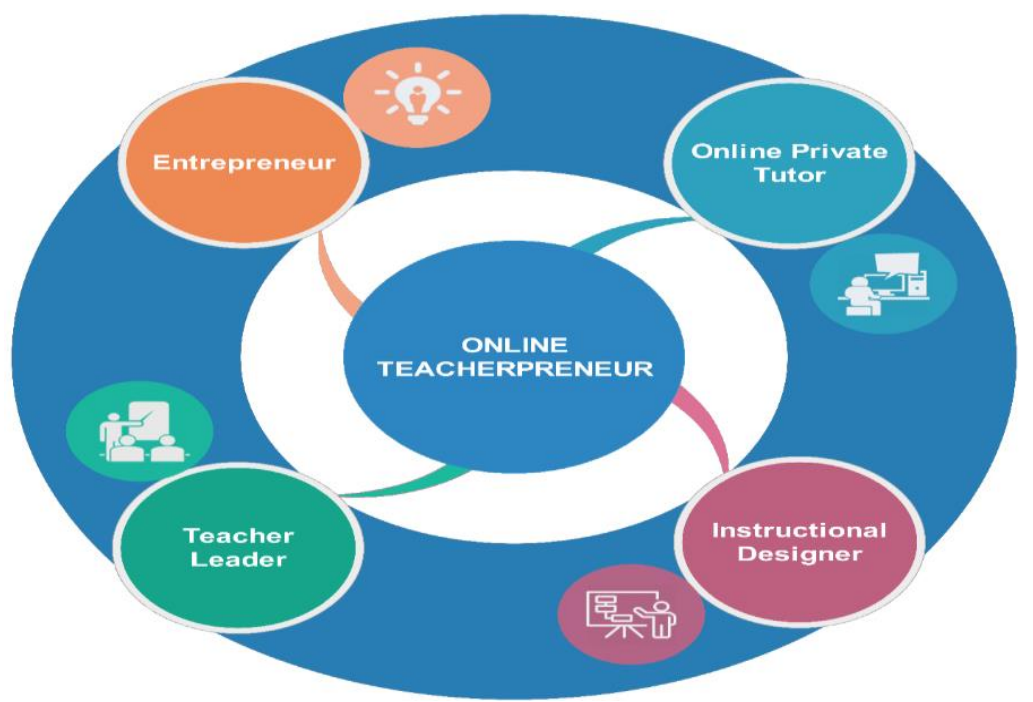

Figure 2: The roles of an online teacherpreneur

Competencies- What online teacherpreneurs are Capable of?

According to Spencer and Spencer (1993), competency is an underlying attribute of an individual that is causally linked to better performance in a job or circumstance. Lucia \& Lepsinger (1999) describe two conceptually-based structures for the creation of competency models: Beginning with a Validated and Starting from Scratch Competency Model. Starting with a validate is a competency model that is generated based on an established competency model and contains the generic competencies needed. They suggest that this approach could be suitable where a competency model has been built for careers with broad duties, roles, and tasks requiring minimal professional abilities and expertise. Regarding teacherpreneurship competence, several attempts have been made to develop and assess the entrepreneurial competencies of teachers. Van Dam, Schipper and Runhaar (2010) build competency-based on entrepreneurial knowledge, three aptitudes (career adaptability, occupational self-efficacy, creative thinking), and two skills (networking skill, teamwork skill). The latest teacherpreneurship competence is based on Arruti \& Paños-Castro's (2020) works, 
they created a competency based on the EntreComp framework (Bacigalupo et al., 2016).

Our competency compilation is presented in four different blocks, corresponding to the roles of online teacherpreneur identified above. Most of the reviewed literature is pulled from generic entrepreneurship, online teaching, instructional designing, and teacher leadership competency frameworks. We believe a competency framework in different settings is more comprehensive and will be universally applicable (Getha-Taylor et al., 2016).

As shown in Table 1, Cluster 1 provides an insight into entrepreneurship competence. The foundation of entrepreneurial competencies is described in the theory of competencies of managerial (Mitchelmore \& Rowley, 2010, p. 99). Boyatzis (1982) mentioned the connection between entrepreneurial and managerial competencies. Since then, studies on the competencies have evolved over the years. We decided to adopt the latest and updated EC model by Draksler and Širec (2018) because it is a combination of several models of entrepreneurial competencies created by Man, Lau and Chan (2002), Kyndt and Baert (2015), and Moberg et al. (2014).

Table 1. Entrepreneurship Competence Areas According to the Compilation of Draksler $\mathcal{E}$ Širec (2018)

\begin{tabular}{|c|c|c|}
\hline \multicolumn{3}{|c|}{ Cluster 1 (Entrepreneurship Competence) } \\
\hline Competence area & Behavioral Focus & Literature source \\
\hline $\begin{array}{l}\text { Competencies for } \\
\text { strategic preparation } \\
\text { for the future }\end{array}$ & $\begin{array}{l}\text { Having skills on how to reduce risk } \\
\text { while planning for the future. }\end{array}$ & $\begin{array}{l}\text { Brinckmann et al. (2010), } \\
\text { Karlsson and Honig (2009), } \\
\text { Kyndt \& Baert (2015) and } \\
\text { Chwolka \& Raith (2012). }\end{array}$ \\
\hline $\begin{array}{l}\text { Competencies of } \\
\text { decisiveness and } \\
\text { commitment }\end{array}$ & $\begin{array}{l}\text { Ability to make specific choices. } \\
\text { Especially choices whose outcomes } \\
\text { are not completely predictable }\end{array}$ & $\begin{array}{l}\text { Wagener et al. (2010), } \\
\text { Rezaei-Zadeh et al. (2014), } \\
\text { Man et al. (2002) }\end{array}$ \\
\hline $\begin{array}{l}\text { Conceptual } \\
\text { competencies }\end{array}$ & $\begin{array}{l}\text { Having conceptual abilities that } \\
\text { can be used in decision-making } \\
\text { abilities, risk-taking, and } \\
\text { innovativeness }\end{array}$ & $\begin{array}{l}\text { Durkan et al. (1993), } \\
\text { Bartlett \& Ghoshall (1997), } \\
\text { Chandler \& Jansen (1992), } \\
\text { Gasse et al. (1997), Baum } \\
\text { (1994), Bird (1995) }\end{array}$ \\
\hline $\begin{array}{l}\text { Organizing } \\
\text { competencies }\end{array}$ & $\begin{array}{lrr}\begin{array}{l}\text { Ability to } \\
\text { physical, }\end{array} \text { financial, } & \text { human, } \\
\text { technological } & \text { resources } & \text { such as } \\
\text { team-building } & \text { and } & \text { staff } \\
\text { management } & & \\
\end{array}$ & $\begin{array}{l}\text { Hunt (1998), Lau et al. } \\
\text { (1999) and Adam and Chell } \\
\text { (1993), }\end{array}$ \\
\hline $\begin{array}{l}\text { Personal strength } \\
\text { competencies }\end{array}$ & $\begin{array}{l}\text { Ability to motivate oneself to } \\
\text { maintain an optimum level of } \\
\text { operation while responding to } \\
\text { constructive criticism. } \\
\text { Ability to identify one's own } \\
\text { strengths and weaknesses, and to } \\
\text { balance them with opportunities } \\
\text { and risks. }\end{array}$ & Man (2001) \\
\hline
\end{tabular}




\begin{tabular}{|c|c|c|}
\hline $\begin{array}{c}\text { Learning } \\
\text { competencies }\end{array}$ & $\begin{array}{l}\text { Ability for constant search for new } \\
\text { information, openness to new } \\
\text { information. }\end{array}$ & $\begin{array}{l}\text { Snell and Lau (1994), Man } \\
\text { (2001) }\end{array}$ \\
\hline $\begin{array}{l}\text { Competencies of } \\
\text { self-knowledge }\end{array}$ & $\begin{array}{l}\text { Possessing self-understanding or } \\
\text { self-awareness as well as self- } \\
\text { confidence skills. }\end{array}$ & Hayward et al. (2010) \\
\hline $\begin{array}{l}\text { Competencies for } \\
\text { market insight }\end{array}$ & $\begin{array}{l}\text { Knowledge of the market that } \\
\text { involve evaluating of potential } \\
\text { risks, recognizing competition and } \\
\text { examining their own market } \\
\text { position }\end{array}$ & $\begin{array}{l}\text { De Clercq et al. (2012) and } \\
\text { Chwolka and Raith (2012) }\end{array}$ \\
\hline $\begin{array}{l}\text { Competencies for } \\
\text { recognizing } \\
\text { opportunities }\end{array}$ & $\begin{array}{l}\text { Ability to identify and exploit } \\
\text { Opportunities }\end{array}$ & $\begin{array}{l}\text { Gras and Mendoza-Abarca } \\
\text { (2014), Rezaei-Zadeh et al. } \\
\text { (2014) }\end{array}$ \\
\hline $\begin{array}{l}\text { Competencies of } \\
\text { building networks } \\
\text { and relationships }\end{array}$ & $\begin{array}{l}\text { Ability to initiate collaboration and } \\
\text { trust, using contacts and networks, } \\
\text { persuasion skills, communication, } \\
\text { and interpersonal skills. }\end{array}$ & $\begin{array}{l}\text { Bird (1995) and Bartlett and } \\
\text { Ghoshall (1997) }\end{array}$ \\
\hline Ability to persuade & $\begin{array}{l}\text { Ability to convince others about } \\
\text { their thoughts, strategies, or } \\
\text { products }\end{array}$ & $\begin{array}{l}\text { Wagener et al. (2010) and } \\
\text { Baron and Markman (2003) }\end{array}$ \\
\hline Independence & $\begin{array}{l}\text { Ability to behave differently from } \\
\text { others. That is, the ability to know } \\
\text { what to do differently to get } \\
\text { outstanding result. }\end{array}$ & $\begin{array}{l}\text { Wagener et al. (2010) and } \\
\text { Rauch and Frese (2007) }\end{array}$ \\
\hline $\begin{array}{l}\text { Awareness of } \\
\text { potential returns on } \\
\text { investments }\end{array}$ & $\begin{array}{l}\text { Ability to assess the strengths and } \\
\text { weaknesses of financial decisions. }\end{array}$ & Man et al. (2002) \\
\hline Perseverance & $\begin{array}{l}\text { Ability to handle risks and cope } \\
\text { with the potential effects }\end{array}$ & $\begin{array}{l}\text { Rauch and Frese (2007) and } \\
\text { Kyndt \& Baert (2015) }\end{array}$ \\
\hline $\begin{array}{l}\text { Entrepreneurial } \\
\text { knowledge }\end{array}$ & $\begin{array}{l}\text { Ability to apply business } \\
\text { knowledge in real-life situation. } \\
\text { That is, moving from theory to } \\
\text { practice }\end{array}$ & $\begin{array}{l}\text { Florin, et al., (2007) and } \\
\text { Moberg et al. (2014) }\end{array}$ \\
\hline Creativity & $\begin{array}{l}\text { Ability to use imagination to solve } \\
\text { a problem }\end{array}$ & Moberg et al. (2014), \\
\hline \multicolumn{3}{|c|}{$\begin{array}{l}\text { Adapted from "Conceptual Research Model for Studying Students' Entrepreneuria } \\
\text { Competencies." by Draksler, T. Z., \& Širec, K., 2018, Naše Gospodarstvo/Our } \\
\text { Economy,p.28 }\end{array}$} \\
\hline
\end{tabular}

As demonstrated in Table 2, Cluster 2 is online teaching competence. Moore and Kearsley (2012) defined online education as a type of teaching that commonly takes place in different settings, requiring contact with technologies and a specific institutional organization. Regarding the aspects of being distant, Finch and Jacobs (2012) defined it as all types of teaching and learning where the student and instructor are geographically and temporally separated. The first development of its teaching competence emerges from the core Seven Principles of Effective Teaching proposed by Chickering \& Gamson (1991). To further validate the critical competencies, Bigatel et al. (2012) conducted a study where faculties were asked to identify the most significant teaching behaviors associated with successful online teaching. The study included 64 teaching tasks, which were 
correlated and evaluated to determine key online tutoring skills. This includes Active Teaching, Policy Enforcement, Classroom Decorum. Farmer and Ramsdale (2016) update this competence by considering the works of Chickering \& Gamson (1989), Goodyear et al. (2001), Berge (1995), and Anderson and Dexter (2005) by adding Leadership \& Instruction, Instructional Design, Community \& Netiquette and Tools \& Technology to the construct.

Table 2. Online Teaching Competence Areas

\begin{tabular}{|c|c|c|}
\hline \multicolumn{3}{|c|}{ Cluster 2 (Online teaching competence) } \\
\hline $\begin{array}{l}\text { Competence } \\
\text { area }\end{array}$ & Behavioral focus & Literature source \\
\hline $\begin{array}{l}\text { Community \& } \\
\text { Netiquette }\end{array}$ & $\begin{array}{l}\text { Ability to create a conducive online learning } \\
\text { atmosphere in classroom and supportive } \\
\text { relationship with students. } \\
\text { Ability to cultivate an inclusive community by } \\
\text { developing activities for learners to connect, } \\
\text { discuss, and collaborate. }\end{array}$ & $\begin{array}{l}\text { Farmer \& Ramsdale } \\
\qquad(2016)\end{array}$ \\
\hline $\begin{array}{l}\text { Classroom } \\
\text { Decorum }\end{array}$ & $\begin{array}{l}\text { Ability to handle course communications by } \\
\text { modeling an expected conduct for all course } \\
\text { communication }\end{array}$ & Bigatel et al. (2012) \\
\hline $\begin{array}{c}\text { Policy } \\
\text { Enforcement }\end{array}$ & $\begin{array}{l}\text { Ability to track students' adherence to } \\
\text { Academic Integrity rules and regulations. }\end{array}$ & \\
\hline $\begin{array}{l}\text { Leadership \& } \\
\text { Instruction }\end{array}$ & $\begin{array}{l}\text { Ability to serve as a leader and facilitator by } \\
\text { directing students, encouraging them to } \\
\text { concentrate on conversations, offering } \\
\text { examples and modeling actions that illustrate } \\
\text { important ideas, values, and skills. }\end{array}$ & $\begin{array}{l}\text { Farmer \& Ramsdale } \\
\text { (2016), }\end{array}$ \\
\hline $\begin{array}{l}\text { Tools \& } \\
\text { Technology }\end{array}$ & $\begin{array}{l}\text { Online teachers should be able to pick and } \\
\text { arrange learning resources and technology. } \\
\text { They are expected to assess and manage course } \\
\text { technology to ensure that tools are effective, } \\
\text { easy for learners of varying ability to use, and } \\
\text { comply with learning outcomes. }\end{array}$ & \\
\hline $\begin{array}{l}\text { Instructional } \\
\text { Design }\end{array}$ & $\begin{array}{l}\text { Ability to apply teaching strategies that } \\
\text { influence the flow of learning materials, } \\
\text { activities, and tests, }\end{array}$ & \\
\hline Active Teaching & $\begin{array}{l}\text { Teachers can create an interactive and } \\
\text { participatory learning atmosphere for online } \\
\text { classroom students. } \\
\text { They also keep learners up to date, provide } \\
\text { input, support group work, modify content, } \\
\text { and review teaching strategies. }\end{array}$ & \\
\hline I'pn & for the onlin & 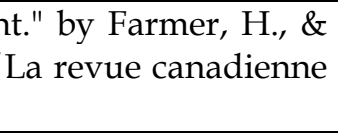 \\
\hline
\end{tabular}

Cluster 3 (instructional designing competence)

Instructional design deals with comprehension, improving, and using material for Instructional purposes (Reigeluth, 2013). The author considers teachers that carried out this professional activity as instructional developers. The scholar further states that the skill helps teachers decide what teaching strategies are 
ideally adapted to cause the desired changes in students' knowledge and skills for particular course content.

Numerous professional organizations have published competencies concerning instructional design. They include IBSTPI, AECT, and the Association for Talent Development (ATD). This study's conceptual framework is the ID's competence model created and validated by the International Board of Standards for Training, Performance, and Instruction (IBSTPI) (Koszalka et al., 2013). It consists of twentytwo competencies and 105 output items divided into five domains (see Table 3). The IBSTPI model is important since it encompasses a range of educational backgrounds, including secondary, vocational and higher education and can be extended to online learning environments. Also, the IBSTPI model describes the professionalization and specialization needs of instructional design in online learning environments and has identified specific skills to the field of online learning specialists, such as Instructional Technology Specialist (Koszalka et al., 2013).

Table 3: Instructional Design Competence Areas According to Koszalka et al. (2013)

\begin{tabular}{|c|c|}
\hline \multicolumn{2}{|c|}{ Cluster 3 (Instructional Design Competence) } \\
\hline Professional Foundations & $\begin{array}{l}\text { 1. Good communications } \\
\text { 2. Research and theory application } \\
\text { 3. Continuous improvement of personal ability } \\
\text { 4. Knowledge of data collection and analysis } \\
\text { 5. Knowledge of legal, ethical, and political } \\
\text { implications of designs }\end{array}$ \\
\hline . Analysis and Planning & $\begin{array}{l}\text { 6. work as needs assessor } \\
\text { 7. Depicting audience and surroundings traits } \\
\text { 8. Deciding content of instruction } \\
\text { 9. Analyzing applicable technologies for use teaching } \\
\text { 10. Decide on suitable instructional material and } \\
\text { development process } \\
\text { 11. Organizing instruction material development } \\
\text { projects }\end{array}$ \\
\hline Design \& Development & $\begin{array}{l}\text { 12. Creating and design of teaching material } \\
\text { interventions } \\
\text { 13. Planning of non-instructional material } \\
\text { interventions } \\
\text { 14. Selecting or modifying of established interventions } \\
\text { 15. Developing of instructional tools } \\
\text { 16. Designing of learning tests }\end{array}$ \\
\hline $\begin{array}{l}\text { Evaluation \& } \\
\text { Implementation }\end{array}$ & $\begin{array}{l}\text { 17. Instructional material's assessment } \\
\text { 18. Instructional material's revision } \\
\text { 19. Instructional material's implementation and } \\
\text { dissemination } \\
\text { 20. Applying of business skills }\end{array}$ \\
\hline Management & $\begin{array}{l}\text { 21. Collaborative relationships } \\
\text { 22. Instructional design projects' planning and } \\
\text { management }\end{array}$ \\
\hline $\begin{array}{l}\text { Adapted from Instructio } \\
\text { Koszalka et al., 2013, Ch } \\
\text { ibstpi®, www.ibstpi.org }\end{array}$ & $\begin{array}{l}\text { igner Competencies: The Standards (4th ed.), by } \\
\text { NC: Information Age Publishing. Copyright } 2012 \text { by }\end{array}$ \\
\hline
\end{tabular}


Cluster 4 (Teacher leadership)

As shown in Table 4, Teacher leadership is a collaborative endeavour that capacitates teachers to conduct significant improvements to the school as a community while building standards for themselves (Greenlee, 2007). A common trait of teacher leadership involves connecting to other teacher leaders, studentteachers, and administrators. (Angelle, 2007). Considering the role of online tools and social media in connecting teachers' networks, various social networking sites offer teacher leaders a platform to exercise their leadership mindset through collaboration and communication. A study has shown how teacher leaders are sharing their knowledge on Facebook through discussions that cover the full spectrum of educational issues (Rutherford, 2010). According to the author, the platform is seen as a medium to promote and support teacher professional development. In an attempt to determine why educators use Instagram, Carpenter (2020) revealed that most educators used the social networking platforms to share ideas and affirmation, with a subset of users monetizing some of the idea exchanges. On this note, we will examine the teacher leadership competency model (TLCM) updated by Yuet, Yusof and Mohamad (2016) through the lens of collaboration and networking on social media. The TLCM was constructed built on the basis of four types of models (Kho, Hamidah \& Syed, 2015). These cover the Framework for Teaching Evaluation Instrument (Danielson, 2013), Teacher Leadership Framework (Centre for Strengthening Teaching Profession, 2009), Teachers as Leaders Framework (Crowther, 2008), and Teacher Leader Model Standards (Teacher Leadership Exploratory Consortium, 2011). Thus, The Teacher Leadership Competency Model (TLCM) proposed for this study, therefore, encompasses Facilitation of Improvement and Establishing Standards; Modeling of Leadership Attributes and Skills; Participating in Organizational Development and Fostering a Collaborative Culture.

Table 4. Teacher Leadership Competency Areas According to Kho et al. (2015)

\begin{tabular}{|c|c|c|}
\hline \multicolumn{3}{|c|}{ Cluster 4 (Teacher leadership competence) } \\
\hline Competence area & Behavioral Focus & Literature source \\
\hline $\begin{array}{l}\text { Facilitating } \\
\text { Improvement and } \\
\text { Establishing } \\
\text { Standards }\end{array}$ & $\begin{array}{l}\text { This involves: } \\
\text { Demonstrating concern in } \\
\text { student well-being and needs } \\
\text { Continuous professional growth } \\
\text { of gifts and talents; } \\
\text { Continuing studies in the area of } \\
\text { pedagogical practice. }\end{array}$ & $\begin{array}{l}\text { Crowther (2008), } \\
\text { Teacher Leader Model } \\
\text { Standards (TLEC, 2011) }\end{array}$ \\
\hline $\begin{array}{l}\text { Fostering a } \\
\text { Collaborative } \\
\text { Culture }\end{array}$ & $\begin{array}{l}\text { Online partnership with others to } \\
\text { promote improvement in student } \\
\text { achievement and school } \\
\text { development. }\end{array}$ & $\begin{array}{l}\text { Barth (2001), Goleman, } \\
\text { Bryatzis \& McKee (2002). } \\
\text { Danielson (2013), CSTP } \\
\text { (2009), and Crowther (2008). }\end{array}$ \\
\hline $\begin{array}{c}\text { Modeling } \\
\text { Leadership } \\
\text { Attributes and Skills }\end{array}$ & $\begin{array}{l}\text { This involves focusing on } \\
\text { compassionate relationships } \\
\text { among teachers and students and } \\
\text { fostering interactions among } \\
\text { students }\end{array}$ & Danielson (2013) \\
\hline $\begin{array}{l}\text { Participating in } \\
\text { Organizational } \\
\text { Development }\end{array}$ & $\begin{array}{l}\text { Teachers are active in school } \\
\text { development programmes. They } \\
\text { assist principals to management }\end{array}$ & Saad \& Sankaran (2013), \\
\hline
\end{tabular}




\begin{tabular}{|l|l|l|}
\hline & $\begin{array}{l}\text { and administration of the school. } \\
\text { They also have the knowledge of } \\
\text { using data for decision-making. }\end{array}$ & $\begin{array}{l}\text { Teacher Leadership } \\
\text { Exploratory Consortium } \\
(2011) .\end{array}$ \\
\hline $\begin{array}{l}\text { Adapted from “Development and validation of the teacher leadership competency } \\
\text { scale." by Yuet, F. K. C, Yusof, H., \& Mohamad, S. I. S., 2016, Malaysian Journal of } \\
\text { Learning and Instruction }\end{array}$
\end{tabular}

\section{Proposed construct}

The competency compilation is presented in Table 5, corresponding to the tasks identified cluster 1. 2, 3 and 4. This includes online teaching competence (Farmer and Ramsdale, 2016), entrepreneurship competence (Draksler \& Širec, 2018), teacher leadership competence schools (Kho Hamidah \& Syed, 2015), and instructional design competence (Koszalka et al., 2013). Here, it is important to add that the existing competencies had to be changed in order to develop a teacherpreneurial competence construct that can be used to examine the impact of online teacherprenurship education on teacherpreneurial competencies and intentions of preservice teacher education. Many of the identified competencies found in all blocks are the same. For example, relationship competence in cluster 1 is similar to fostering collaboration in teacher leadership competence, leadership instruction in online teaching overlapped with teacher leadership competence. In addition, instruction design in online teaching is covered in instruction design competence. After merging the competencies, we obtained the final 30 competence constructs.

\section{Table 5: Proposed Teacherpreneurial Constructs}

\begin{tabular}{|l|l|}
\hline \multicolumn{1}{|c|}{ Teacherpreneurial Competencies } & \multicolumn{1}{c|}{ Literature source } \\
\hline $\begin{array}{l}\text { Competencies for strategic preparation } \\
\text { for the future }\end{array}$ & $\begin{array}{l}\text { Kyndt and Baert (2015), Man } \text { et al. (2002), } \\
\text { Man (2001) }\end{array}$ \\
\hline $\begin{array}{l}\text { Competencies of determination and } \\
\text { dedication }\end{array}$ & $\begin{array}{l}\text { Kyndt and Baert (2015), Man } \text { et al. (2002), } \\
\text { Man (2001), }\end{array}$ \\
\hline Conceptual competences & Man et al. (2002), Man (2001) \\
\hline Organizing competencies & Man et al. (2002), Man (2001) \\
\hline Personal strength competencies & Man et al. (2002), Man (2001) \\
\hline Learning competencies & $\begin{array}{l}\text { Kyndt and Baert (2015), Man } \text { et al. (2002), } \\
\text { Man (2001) }\end{array}$ \\
\hline Competencies of self-knowledge & Kyndt and Baert (2015) \\
\hline Competencies for business insight & Kyndt and Baert (2015 \\
\hline $\begin{array}{l}\text { Competencies for the identification of } \\
\text { opportunities }\end{array}$ & $\begin{array}{l}\text { Kyndt and Baert (2015), Man } \text { et al. (2002), } \\
\text { Man (2001) }\end{array}$ \\
\hline $\begin{array}{l}\text { Networks and partnership } \\
\text { competencies }\end{array}$ & $\begin{array}{l}\text { Kyndt and Baert (2015), Man } \text { et al. (2002), } \\
\text { Man (2001) }\end{array}$ \\
\hline Capacity to persuade & Kyndt and Baert (2015) \\
\hline Independence & Kyndt and Baert (2015) \\
\hline $\begin{array}{l}\text { Knowledge of future returns on } \\
\text { investments }\end{array}$ & Kyndt and Baert (2015) \\
\hline Perseverance & Kyndt and Baert (2015) \\
\hline Knowledge of Entrepreneurship & Moberg et al. (2014) \\
\hline Creativity & Moberg et al. (2014) \\
\hline Professional Foundations & $\begin{array}{l}\text { Koszalka et al. (2013) } \\
\text { www.ibstpi.org }\end{array}$ \\
\hline Planning \& Analysis &
\end{tabular}




\begin{tabular}{|c|c|}
\hline Design \& Development & \\
\hline Evaluation \& Implementation & \\
\hline Project Management & \\
\hline Online Active Teaching & $\begin{array}{l}\text { Farmer and Ramsdale (2016), Bigatel et al. } \\
\text { (2012) }\end{array}$ \\
\hline Online Classroom Decorum & \\
\hline Online Policy Enforcement & \\
\hline Community \& Netiquette & \\
\hline Tools \& Technology & \\
\hline $\begin{array}{l}\text { Facilitating Improvement and } \\
\text { Establishing Standards }\end{array}$ & $\begin{array}{l}\text { Yuet et al. (2016), Norazlinda Saad and } \\
\text { Surendran Sankaran (2013), Teacher }\end{array}$ \\
\hline Fostering a Collaborative Culture & Leadership Exploratory Consortium (2011), \\
\hline $\begin{array}{l}\text { Modeling Leadership Attributes and } \\
\text { Skills }\end{array}$ & Danielson (2013) \\
\hline $\begin{array}{l}\text { Participating in Organizational } \\
\text { Development }\end{array}$ & \\
\hline
\end{tabular}

\section{Impact of Online Teacherpreneurship Education on Students' Learning Outcome}

This study aims to conceptualize the impact of online teacherpreneurship education on students' EC, EI, and perceived employability. The justification for its inclusion in preservice teacher education is similar to various higher institutions' EE program objectives (Deveci \& Seikkula-Leino, 2018; Qureshi, Khanam \& Aziz, 2018). This includes developing an entrepreneurial mindset of students to disrupt precarious employment in education and augment their low wages by developing innovative teaching ideas.

Considering that this form of education rest on the ability to teach online, share ideas and material online, giving the current pandemic situation which has provided the needed courage to embrace online teaching and learning, we can argue for the need to integrate Online Teacherpreneurship Education (OTE) in preservice teacher education.

The first critical step in implementing OTE is by defining the role of online teacherpreneur. We argue that their practice should be based on their ability to teach online, design and sell instructional material, and consult and collaborate in the area of educational leadership. Thirty comprehensive constructs were developed from the existing competencies on entrepreneurship (Draksler \& Širec, 2018), online teaching (Farmer and Ramsdale, 2016), instructional design (Koszalka et al., 2013), and teacher leadership (Kho, Hamidah \& Syed, 2015). This conforms to previous studies on a conceptual framework to study EE's impact on EC (Draksler \& Širec, 2018). This is the first approach towards the development of the curriculum or syllabus needed for OTE.

To further assess the impact of OTE, perceived self-assessment of entrepreneurship competence can be carried out. Based on self-perception theory that states individuals perceive the contingencies influencing their actions and infer their attitudes from the pattern of freely chosen action (Deci., Koestner \& 
Ryan, 1999). Thus, the impact can be measured by evaluating the degree at which they perceive their competence. That is, putting entrepreneurship theory into practice, using their ability to teach online, designing instructional material, and offering teacher leadership-consulting service.

On the other hand, EI can be considered the second level of evaluating the impact of education on students learning outcomes. According to human capital theory, an individual with greater competency levels will achieve more significant performance outcomes (EI) (Martin, McNally \& Kay, 2013). That is, students' EI can be influenced by the attitude towards a certain kind of behavior and self-efficacy (Krueger, 2003). Several studies have suggested ways of increasing learners' entrepreneurial intentions (Ozaralli \& Rivenburgh, 2016: Mueller, 2011). This involves adopting a model and student-oriented teaching model to boost their attitude, emotional, and experiential learning (Ozaralli \& Rivenburgh, 2016).

Perceived employability is described as achieving sustainable employment appropriate to one's qualification level (Rothwell, Herbert \& Rothwell, 2008). A recent study has shown that the higher an individual perceived their future employability, the higher their entrepreneurial intention (Atitsogbe et al., 2019). Note that online OTE is not solely designed to make teachers set up an enterprise, but to disrupt precarious employment, innovate teaching skills and supplement their income. Thus, perceived employment can be used to assess the quality of the impact of tp education. This agrees with other entrepreneurship education programs used to promote employability among university students (PardoGarcia \& Barac, 2020).

On the other hand, precarious employment in the educational sector has been argued to be caused by the teacher's inability to explore employment outside mainstream education (Lasekan, 2019: Lasekan, Moraga \& Galvez, 2020). The authors stated this argument in the case of the English language teaching sector, where different teaching opportunities in non-mainstream education are yet to be explored. For example, English teachers can teach English for Specific Purposes in private companies (Lasekan, 2019) and physical education teachers can offer teaching services in the fitness centers (Adeogu \& Adeyemi, 2012). OTE can help students understand the job prospects available in mainstream and nonmainstream education of their discipline. Thus, the main goal of EE is to instruct students to grasp the internal situation of the industry. Therefore, the OTE objective should be focused on the development status, the development pattern of several industries, to foster the comprehensive cultivation of students' employability based on industry needs ( $\mathrm{Li}, 2017)$. 


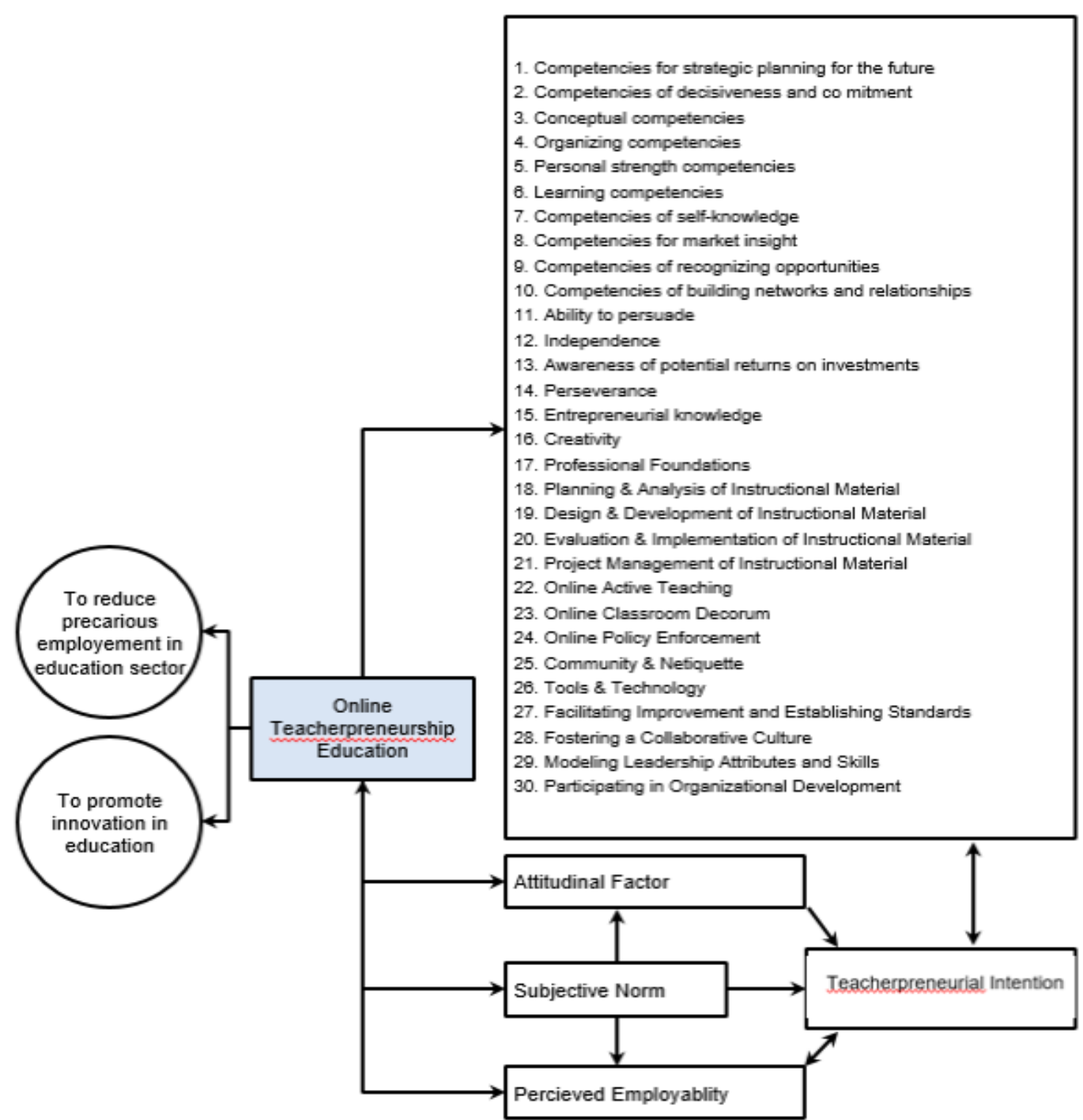

Figure 3: Conceptual research framework to investigate the impact of online teacherpreneurship education on students' teacherpreneurship competencies and intentions as well as employability. Adapted from "Conceptual Research Model for Studying Students' Entrepreneurial Competencies" by Draksler, T. Z., \& Širec, K. 2018, Naše gospodarstvo/Our economy, p. 28

\section{Discussion}

In reviewing the literature, no data was found on integrating online teacherpreneurship education in student-teacher education. To fill the gap, it is critical to developing a competency framework needed to create a curriculum for the online teacherpreneurship program. Thus, this study set out to develop a research competency model for online teacherpreneurship that can be used to assess the impact of its education on students' EC, EI, and employability skills.

This framework adopted involves a model that begins with a validated competency. It is a method that generates a model based on an established competency model that contains the generic competencies required (Lucia \& Lepsinger, 1999). For example, entrepreneurship, online teaching, instructional designing, and teacher leadership are adopted as the core competencies of online teacherpreneurship competencies. Key competencies from all these are 
synthesized to develop online teacherpreneurship competency. This approach is similar to the system of competencies for sustainability entrepreneurship created by Foucrier and Wiek (2019).

The second part of this study involves conceptualizing a model that can assess online teacherpreneurship education's impact on students' online teacherpreneural competence, intentions, and perceived employability. We argue that education's main objective is to disrupt precarious employment in the educational sector and promote teaching innovations. Thus, a robust OTE is expected to address all the core competencies of an online teacherpreneur. EI is the second level to evaluate the impact of education. This assessment is based on the learner's significant level of competencies acquired (Al Mamun, Nawi \& Shamsudin 2016). This is also subjected to several affective and attitudinal factors (Liñán et al., 2011). Perceived employability skill is the final assessment used to evaluate the perceived degree at which students can secure a job easily and disrupt precarious employment. This conceptual model is similar to the model developed for examining the impact of Entrepreneurship Education on Entrepreneurial Competencies and Entrepreneurial Intentions (Draksler \& Širec, 2018). This education is considered essential for both in-service and preservice education. This is because of the emerging practice of online teacherpreneurship among teachers (Shelton, 2018). Thus, it is possible that many prospective teachers will, at some point in the future, explore professional usage of social media for either collaborating or selling of ideas or instructional material (Carpenter et al., 2020). However, the authors' primary concern on the practice is centered on the possibility of some teachers to view their fellow teachers as potential clients rather than as colleagues with whom they should be in solidarity and with whom they could engage in collaborative action.

The development of entrepreneurship competency frameworks is critical to the successful implementation of entrepreneurship education. Thus, we believe that the starting point for successfully implementing online teacherpreneurship education should be developing its competency framework. The justification of the need to inculcate online teacherpreneurship education in preservice education is similar to other reasons in several contexts (Whitty, 2000: Shelton \& Archambault, 2019). These include fostering teachers' professionalism (Whitty, 2000) and training of teachers so that they can meet the demand of 21st-century challenges, which require the utilization of ICT and the mastery of special skills (Trilling and Fadel (2009)) and supplement their income (Shelton \& Archambault, 2019). For effective implementation, the competency framework should operationalize and assess online teacherpreneurship skills (Chapman \& O'Neill, 2010). Thus, OTE needs to focus on the outcomes in terms of learners' competencies rather than on program-specific information gains (Giangrande et al., 2019).

Overall, the approach adopted in this study is more application-oriented and is especially well known in the literature on training and development. It focuses on identifying the competencies that are supposed to be added to EE, which can be used to assess its effectiveness in the preservice teacher education program 
(Gorman et al., 1997). It is also an approach that clarifies the importance of the skills and knowledge necessary for entrepreneurial success and the psychological traits that are appropriate for that purpose.

\section{Conclusion}

This study was designed to conceptualize a research model for studying the impact of online teacherpreneurship education on students' teacherpreneural competencies and intentions in preservice teacher education. This requires developing a framework of competencies that online teacherpreneurs would ideally possess. The framework is constructed with various strands of competencies such as online teaching (Farmer \& Ramsdale, 2016), instructional design (Koszalka et al., 2013), entrepreneurship (Draksler \& Širec, 2018), and teacher leadership competence (Kho, Hamidah \& Syed, 2015). This is integrated into a teacherpreneural educational discourse by creating a model that investigates its impact on students' learning outcomes in preservice education. A significant finding is a conceptual development of how to study the impact assessment of enterprise education among student-teachers in preservice teacher education. This is a scholarly response to a call on the need to integrate online teacherpreneurship education in preservice teacher education programs to help aspiring educators leverage social media's learning affordances and mitigate its challenges (Carpenter et al., 2020). It is the first study to construct a competency framework for Online teacherpreneurship education. The proposed education has important implications for reducing precarious employment and foster innovation in the educational sector. Though the latest and comprehensive competence frameworks were adopted, the framework is still generic and therefore does not capture all context-specific of the compiled competencies. For example, all existing competencies available in the literature from several contexts were not considered while developing the proposed competence. Thus, this compilation needs to be interpreted with caution when applying to a specific context. Therefore, further empirical research would be required to demonstrate real-world online teacherpreneurship practices to verify the practices of online teacherpreneurs. This can be carried out by first developing and validating an instrument aligned with learning-teaching settings and pedagogies that are most suited to convey the competencies of online teacherpreneurship.

\section{References}

Adam, E., \& Chell, E. (1993). The successful international entrepreneur: a profile. Paper Presented to the 23rd European Small Business Seminar. Belfast.

Adeogu, W., \& Adeyeye, A. (2012). Entrepreneurship in sports and physical education in Nigerian universities: Challenges and prospects. In Entrepreneurial Education and Sustainable National Development. Lagos: Proceeding of Lagos State University Faculty of Education international conference.

Al Mamun, A., Nawi, N. B. C., \& Shamsudin, S. F. F. B. (2016). Examining the effects of entrepreneurial competencies on students' entrepreneurial $\begin{array}{llll}\text { intention. Mediterranean Journal of Social } & \text { Sciences, 7(2), } & 119 .\end{array}$ doi:10.5901/mjss.2016.v7n2p119

Albornoz Pardo, C. (2013). Is business creation the mean or the end of entrepreneurship education?: a multiple case study exploring teaching goals in entrepreneurship 
education. Journal of technology management $\mathcal{E}$ innovation, 8(1), 1-10. doi:10.4067/s0718-27242013000100001

Allegretto, S., \& Mishel, L. (2018). The Teacher Pay Penalty Has Hit a New High: Trends in the Teacher Wage and Compensation Gaps through 2017. Economic Policy Institute. Retrieved from https://files.eric.ed.gov/fulltext/ED593401.pdf

Allo, M. D. G. (2020). Is the online learning good in the midst of Covid-19 Pandemic? The case of EFL learners. Jurnal Sinestesia, 10(1), 1-10.

Anderson, R. E., \& Dexter, S. (2005). School technology leadership: An empirical investigation of prevalence and effect. Educational Administration Quarterly, 41(1), 49-82. doi:10.1177/0013161X04269517

Angelle, P. S. (2007). What research says: Teachers as leaders: Collaborative leadership for learning communities. Middle School Journal, 38(3), 54-61.

Arruti, A., \& Paños Castro, J. (2019). Análisis de las menciones del grado en Educación Primaria desde la perspectiva de la competencia emprendedora [Analysis of the mentions of the Primary Education degree from the perspective of entrepreneurial competence]. Revista Complutense de Educación, 30(1). doi: $10.5209 /$ rced.55448

Arruti, A., \& Paños-Castro, J. (2020). How Do Future Primary Education Student Teachers Assess Their Entrepreneurship Competences? an Analysis of Their SelfPerceptions. Journal of Entrepreneurship Education, 23(1), 1-13.

Aryanto, S., Ariffiando, N. F., \& Andriani, E. N. (2017). Teacherpreneurship Based Local Wisdom as an Attempt to Develop The Character Of The 21st Century Teachers in Primary Schools. Prossiding Basic Education and Early Childhood, 2(1), 630-634.

Ashari, R., Syam, A. R., \& Budiman, A. (2017). The World Challenge of Islamic Education Toward Human Resources Development. Proceeding International Conference on Islamic Education (ICIED), 169-175. Retrieved from http://conferences.uinmalang.ac.id/index.php/icied/article/view/451

Atitsogbe, K. A., Mama, N. P., Sovet, L., Pari, P., \& Rossier, J. (2019). Perceived employability and entrepreneurial intentions across university students and job seekers in Togo: The effect of career adaptability and self-efficacy. Frontiers in psychology, 10, 180. doi:10.3389/fpsyg.2019.00180

Bacigalupo, M., Kampylis, P., Punie, Y., \& Van den Brande, G. (2016). EntreComp: The entrepreneurship competence framework. Luxembourg: Publication Office of the European Union, 10, 593884.

Baker, D., \& Le Tendre, G. (2005). Demand for achievement: the worldwide growth of shadow education systems. National Differences, Global Similarities. World Culture and the Future of Schooling, 54-70.

Bancotovska, S. N. (2015). The attitudes and opinions of teachers to their competences. International Journal of Cognitive Research in Science, Engineering and Education, 3(1), 99-103. doi:10.23947/2334-8496-2015-3-1-99-103

Baron, R. A., \& Markman, G. D. (2003). Beyond social capital: The role of entrepreneurs' social competence in their financial success. Journal of Business Venturing, 18, $41-$ 60. doi:10.1016/S08839026(00)00069-0

Barth, R. S. (2001). Teacher leader. Phi Delta Kappan, 82(6), 443-449.

Bartlett, C. A., \& Ghoshal, S. (1997). The myth of the generic manager: new personal competencies for new management roles. Calif.Manage. Rev., 40(1), 92-116. https:// doi.org/10.2307/4116592

Baum, J. R. (1994). The relationship of traits, competencies, motivation, strategy and structure to venture growth. PhD dissertation, University of Maryland, USA.

Berge, Z. L. (1995). The role of the online instructor/facilitator. Educational technology, 35(1), 22-30. 
Berry, B. (2011). Teacherpreneurs: A more powerful vision for the teaching profession. Phi Delta Kappan, 92(6), 28-33. doi:10.1177/003172171109200606

Berry, B., Byrd, A., \& Wieder, A. (2013). Teacherpreneurs: Innovative teachers who lead but don't leave. John Wiley \& Sons.

Bigatel, P. M., Ragan, L. C., Kennan, S., May, J., \& Redmond, B. F. (2012). The identification of competencies for online teaching success. Journal of Asynchronous Learning Networks, 16(1), 59-77. doi:10.24059/olj.v16i1.215

Bingham, C. S. (2017). What is a Teacherpreneur? Ask Sarah Henchey.

Bird, B. (1995). Toward a theory of entrepreneurial competency. In J. A. Katz \& R. H. Brockhaus (Eds.), Advances in entrepreneurship, firm emergence, and growth, 2, 51-72. Greenwich, Connecticut: JAI Press Inc.

Boyatzis, R. E. (1982). The competent manager: A model for effective performance. John Wiley \& Sons.

Brand, M., Wakkee, I., \& Van der Veen, M. (2007). Teaching entrepreneurship to nonbusiness students: Insights from two Dutch universities. Handbook of Research in Entrepreneurship Education: Contextual Perspectives, 2, 52-83.

Bray, M. (2006). Private supplementary tutoring: Comparative perspectives on patterns and implications. Compare, 36(4), 515-530.

Brinckmann, J., Grichnik, D., \& Kapsa, D. (2010). Should entrepreneurs plan or just storm the castle? A meta-analysis on contextual factors impacting the business planning-performance relationship in small firms. Journal of Business Venturing, 25, 24-40. doi:10.1016/j.jbusvent.2008.10.007

Buckley, A. P., \& Nzembayie, K. F. (2016, May). Teacherpreneurs: From vocation to innovation. In ICIE2016-Proceedings of the 4th International Conference on Innovation and Entrepreneurship: ICIE2016 (p. 36).

Carpenter, J. P., Morrison, S. A., Craft, M., \& Lee, M. (2020). How and why are educators using Instagram?. Teaching and Teacher Education, 96, 103149. doi:10.1016/j.tate.2020.103149

Centre for Strengthening the Teaching Profession (2009). Teacher leadership skills framework. Retrieved from http://www.cstp-wa.org.

Chandler, G., \& Jansen, E. (1992). The founder's self-assessed competence and venture performance. Journal of Business Venturing, 7(3), 223-236. doi:10.1016/08839026(92)90028-P

Chapman, E., \& O'Neill, M. (2010). Defining and assessing generic competencies in Australian universities: Ongoing challenges. Education research and perspectives, 37(1), $105 . \quad$ Retrieved from https://search.informit.org/doi/10.3316/informit.086552707509215 (Original work published January 2010)

Chickering, A. W., \& Gamson, Z. F. (1989). Seven principles for good practice in undergraduate education. Biochemical Education, 17(3), 140-141. doi:10.1016/0307-4412(89)90094-0

Chickering, A., \& Gamson, Z. (Eds.). (1991). Applying the seven principles for good practice in undergraduate education. (47th ed.). San Francisco: Jossey-Bass.

Chwolka, A., \& Raith, M. G. (2012). The value of business planning before start-up: A decision-theoretical perspective. Journal of Business Venturing, 27(3), 385-399. doi:10.1016/j.jbusvent.2011.01.002

Crowther, F. (2008). Teachers as leaders framework. Retrieved from http://www.corwin.com/upm-data/25560_1204_Crowther_Ch_1_excerpt.pdf

Danielson, C. (2013). The framework for teaching evaluation instrument. Retrieved from http://www.frame work for teaching 
De Clercq, D., Sapienza, H. J., Yavuzc, R. I., \& Zhoua, L. (2012). Learning and knowledge in early internationalization research: Past accomplishments and future directions. Journal of Business Venturing, 27, 143-165. doi:10.1016/j.jbusvent.2011.09.003

Deci, E. L., Koestner, R., \& Ryan, R. M. (1999). A meta-analytic review of experiments examining the effects of extrinsic rewards on intrinsic motivation. Psychological bulletin, 125(6), 627. doi:10.1037/0033-2909.125.6.627

Deveci, İ., \& Seikkula-Leino, J. (2018). A review of entrepreneurship education in teacher education. Malaysian Journal of Learning and Instruction, 15(1), 105-148. doi:10.32890/mjli2018.15.1.5

Draksler, T. Z., \& Širec, K. (2018). Conceptual Research Model for Studying Students' Entrepreneurial Competencies. Naše gospodarstvo/Our economy, 64(4), 23-33. doi:10.2478/ngoe-2018-0020

Durkan, P., Harrison, R., Lindsay, P., \& Thompson, E. (1993). Competence and executive education and development in an SME environment. Irish Bus. Adm. Res., 14(1), 65-80.

Duval-Couetil, N., Reed-Rhoads, T., \& Haghighi, S. (2012). Engineering students and entrepreneurship education: Involvement, attitudes and outcomes. International Journal of Engineering Education, 28(2), 425.

Farmer, H., \& Ramsdale, J. (2016). Teaching competencies for the online environment. Canadian Journal of Learning and Technology/La revue canadienne de l'apprentissage et de la technologie, 42(3). doi:10.21432/t2v32j

Farooq, F., Rathore, F. A., \& Mansoor, S. N. (2020). Challenges of online medical education in Pakistan during COVID-19 pandemic. J Coll Physicians Surg Pak, 30, 67-9. doi:10.29271/jcpsp.2020.supp1.s67

Feriady, M., \& Santoso, A. (2020). Teacherpreneurship Determination Toward Teacher Innovation and Competitive Advantage in the Disruption Era: Application of Strategic Entrepreneurship Theory in Educational Institutions. KnE Social Sciences, 787-797. doi:10.18502/kss.v4i6.6642

Finch, D., \& Jacobs, K. (2012, September). Online education: Best practices to promote learning. In Proceedings of the human factors and ergonomics society annual meeting (Vol. 56, No. 1, pp. 546-550). Sage CA: Los Angeles, CA: SAGE Publications. doi:10.1177/1071181312561114

Florin, J., Karri, R., \& Rossiter, N. (2007). Fostering entrepreneurial drive in business education: An attitudinal approach. Journal of management education, 31(1), 17-42. doi:10.1177/1052562905282023

Foucrier, T., \& Wiek, A. (2019). A process-oriented framework of competencies for sustainability entrepreneurship. Sustainability, 11(24), 7250. doi:10.3390/su11247250

Gasse, Y., d'Amboise, G., Simard, G., \& Lasker, K. (1997). Entrepreneurial-Managerial Competencies and Practices of Growing SMEs-Summary of Results from an Empirical Study (Preliminary). Centre for Entrepreneurship and SME and Entrepreneuriat Laval, Université Laval, Montréal.

Getha-Taylor, H., Blackmar, J., \& Borry, E. L. (2016). Are competencies universal or situational? A state-level investigation of collaborative competencies. Review of Public Personnel Administration, 36(3), 306-320. doi:10.1177/0734371×15624132

Giangrande, N., White, R. M., East, M., Jackson, R., Clarke, T., Saloff Coste, M., \& PenhaLopes, G. (2019). A competency framework to assess and activate education for sustainable development: Addressing the UN sustainable development goals 4.7 challenge. Sustainability, 11(10), 2832. doi:10.3390/su11102832 
Gibb, A. (2005). Towards the entrepreneurial university: entrepreneurship education as a lever for change. Policy paper, 3, 1-46.

Goh, P. S., \& Sandars, J. (2020). A vision of the use of technology in medical education after the COVID-19 pandemic. MedEdPublish, 9. doi:10.15694/mep.2020.000049.1

Goleman, D., Boyatzis, R., \& McKee, A. (2002). Primal leadership: Realizing the power of emotional intelligence. Boston: Harvard Business School Press. doi:10.1108/jocm.2003.16.1.123.3

Goodyear, P., Salmon, G., Spector, J. M., Steeples, C., \& Tickner, S. (2001). Competences for online teaching: A special report. Educational Technology Research and Development, 49(1), 65-72. doi:10.1007/bf02504508

Gorman, G., Hanlon, D., \& King, W. (1997). Some research perspectives on entrepreneurship education, enterprise education and education for small business management: a ten-year literature review. International small business journal, 15(3), 56-77. doi:10.1177/0266242697153004

Gras, D., \& Mendoza-Abarca, K. I. (2014). Risky business? The survival implications of exploiting commercial opportunities by nonprofits. Journal of Business Venturing, 29(3), 392-404. doi:10.1016/j.jbusvent.2013.05.003

Greenlee, B. J. (2007). Building teacher leadership capacity through educational leadership programs. Journal of Research for Educational Leaders, 4(1), 44-74.

Hattab, H. W. (2014). Impact of entrepreneurship education on entrepreneurial intentions of university students in Egypt. The Journal of Entrepreneurship, 23(1), 1-18. doi:10.1177/0971355713513346

Hayward, M. L. A., Forster, W. R., Sarasvathy, S. D., \& Fredrickson, B. L. (2010). Beyond hubris: How highly confident entrepreneurs rebound to venture again. Journal of Business Venturing, 25, 569-578. doi:10.1016/j.jbusvent.2009.03.002

Holland, J. M., Eckert, J., \& Allen, M. M. (2014). From preservice to teacher leadership: Meeting the future in educator preparation. Action in Teacher Education, 36(5-6), 433- 445. doi:10.1080/01626620.2014.977738

Hunt, J. M. (1998). Toward the development of a competency model of family firm leadership. Paper Presented to the 12th Annual National Conference (pp. 15-18). Clearwater, FL: United States Association for Small Business and Entrepreneurship.

Karlsson, T., \& Honig, B. (2009). Judging a business by its cover: An institutional perspective on new ventures and the business plan. Journal of Business Venturing, 24, 27-45. doi:10.1016/j.jbusvent.2007.10.003

Katz, J. A. (1992). A psychosocial cognitive model of employment status choice. Entrepreneurship theory and practice, 17(1), 29-37. doi:10.1177/104225879201700104

Keyhani, N., \& Kim, M. S. (2020). A Systematic Literature Review of Teacher Entrepreneurship. Entrepreneurship Education and Pedagogy, doi:10.1177/2515127420917355

Kho, F. C. Y., Hamidah ,Y., \& Syed I. S. M. (2015). The power of leadership for learning: Developing niche-Malaysian Teachers' leadership competency model. Paper presented at the International Conference on Accounting Studies, Johor Bahru, Malaysia.

Koszalka, T. A., Russ-Eft, D. F., \& Reiser, R. (2013). Instructional designer competencies: The standards, (4th ed.). Charlotte, NC: Information Age Publishing, Inc.

Krueger, N. F. (2003). The cognitive psychology of entrepreneurship. In Handbook of entrepreneurship research (pp. 105-140). Springer, Boston, MA.

Kyndt, E., and Baert, H. (2015). Entrepreneurial competencies: Assessment and predictive value for entrepreneurship. Journal of Vocational Behavior, 90, 13-25. doi:10.1016/j.jvb.2015.07.002 
Lau, T., Chan, K. F., \& Man, T. W. Y. (1999). Entrepreneurial and managerial competencies: small business owner-managers in Hong Kong. In Fosh, P., Chan, A. W., Chow, W. W. S., Snape, E., Westwood, R. (Eds.), Hong Kong Management and Labour: Change and Continuity. London: Routledge.

Lasekan, O.A. (2019). How well prepared are Chilean beginning English teachers to meet job demands in English language teaching industry? Journal of Entrepreneurship Education, 22(6). Retrieved from https://www.abacademies.org/articles/Howwell-prepared-are-chilean-beginning-english-1528-2651-22-6-480.pdf

Lasekan, O., Moraga, A., \& Galvez, A. (2020). Online Marketing by Private English Tutors in Chile: A Content Analysis of a Tutor Listing Website. International Journal of Learning, Teaching and Educational Research, 18(12). doi:10.26803/ijlter.18.12.4

Lasekan, O. A., Moraga, A., Quezada, C., \& Alvarez, B. (2020). Precarious Employment in the Chilean English Language Teaching Industry. Universal Journal of Educational Research, 8(11B), 6000- 6013. doi:10.13189/ujer.2020.082236

Li, G. (2017). Role of innovation and entrepreneurship education in improving employability of Medical University students. EURASIA Journal of Mathematics, Science and Technology Education, 13(12), 8149-8154. doi:10.12973/ejmste/80779

Liñán, F., Rodríguez-Cohard, J. C., \& Rueda-Cantuche, J. M. (2011). Factors affecting entrepreneurial intention levels: a role for education. International entrepreneurship and management Journal, 7(2), 195-218. doi:10.1007/s11365-010-0154-z

Lucia, A. D., \& Lepsinger, R. (1999). The art and science of competency models. San Francisco, CA: Jossey-Bass.

Maldifassi, J. O. (2001). Entrepreneurship and innovation in Chilean firms: an exploratory study. International Journal of Entrepreneurship and Innovation Management, 1(1), 73 95. doi:10.1504/ijeim.2001.000446

Man, T. W. (2001). Entrepreneurial competencies and the performance of small and medium enterprises in the Hong Kong services sector (Doctoral dissertation, The Hong Kong Polytechnic University).

Man, T. W., Lau, T., \& Chan, K. F. (2002). The competitiveness of small and medium enterprises: A conceptualization with focus on entrepreneurial competencies. Journal of business venturing, 17(2), 123-142. doi:10.1016/S0883-9026(00)00058-6

Martin, C., \& Iucu, R. B. (2014). Teaching entrepreneurship to educational sciences students. Procedia-Social and Behavioral Sciences, 116(5). doi:10.1016/j.sbspro.2014.01.954

Martin, B. C., McNally, J. J., \& Kay, M. J. (2013). Examining the formation of human capital in entrepreneurship: A meta-analysis of entrepreneurship education outcomes. Journal of business venturing, 28(2), 211-224. doi:10.1016/j.jbusvent.2012.03.002

Mitchelmore, S., \& Rowley, J. (2010). Entrepreneurial competencies: a literature review and development agenda. International journal of entrepreneurial Behavior $\mathcal{E}$ Research. doi:10.1108/13552551011026995

Moberg, K., Vestergaard, L., Fayolle, A., Redford, D., Cooney, T., Singer, S., \& Filip, D. (2014). How to assess and evaluate the influence of entrepreneurship education: A report of the ASTEE project with a user guide to the tools. The Danish Foundation for Entrepreneurship-Young Enterprise.

Moore, M. G., \& Kearsley, G. (2012). Distance education: A systematic view of online learning. United Kingdom: Wadsworth Cengage Learning.

Moreland, N. (2006). Entrepreneurship and higher education: an employability perspective (Vol. 6). York: Higher Education Academy. 
Mueller, S. (2011). Increasing entrepreneurial intention: effective entrepreneurship course characteristics. International Journal of Entrepreneurship and Small Business, 13(1), 55-74. doi:10.1504/ijesb.2011.040416

Ni' mah, F. U., Siswandari, M., \& Indrawati, C. D. S. (2018). The effects of teacherpreneurship, multicultural personality. International Journal of Education and Social Science Research, 1(5), 44-56.

O'Leary, S. (2012). Impact of entrepreneurship teaching in higher education on the employability of scientists and engineers. Industry and Higher Education, 26(6), 431-442. doi:10.5367/ihe.2012.0128

Oplatka, I. (2014). Understanding teacher entrepreneurship in the globalized society. Journal of Enterprising Communities: People and Places in the Global Economy, 8(1), 2033. doi:10.1108/JEC-06-2013-0016

Ozaralli, N., \& Rivenburgh, N. K. (2016). Entrepreneurial intention: antecedents to entrepreneurial behavior in the USA and Turkey. Journal of Global Entrepreneurship Research, 6(1), 3. doi:10.1186/s40497-016-0047-x

Palmer, P. (2017), An online course "From teacher to teacherpreneur". Retrieved from http://itdi.pro/itdihome/teacherpreneur.php.

Pardo-Garcia, C., \& Barac, M. (2020). Promoting Employability in Higher Education: A Case Study on Boosting Entrepreneurship Skills. Sustainability, 12(10), 4004. doi:10.3390/su12104004

Qureshi, U., Khanam, A., \& Aziz, F. (2018). Women Teacherpreneurship: Development and Dissemination of Entrepreneurship Modules for Teacher Education Programs in Punjab. Global J. Bus. Soc. Sci. Review, 6(1), 44-53.

Rae, D., \& Woodier-Harris, N. (2012). International entrepreneurship education: Postgraduate business student experiences of entrepreneurship education. Education+ Training, 54(8-9), 639-656. doi:10.1108/00400911211274800

Rajab, M. H., Gazal, A. M., \& Alkattan, K. (2020). Challenges to Online Medical Education During the COVID-19 Pandemic. Cureus, 12(7). doi:10.7759/cureus.8966

Rauch, A., \& Frese, M. (2007). Let's put the person back into entrepreneurship research: A meta-analysis on the relationship between business owners' personality traits, business creation, and success. European Journal of Work and Organizational Psychology, 16, 353-385. doi:10.1080/13594320701595438

Reigeluth, C. M. (Ed.). (2013). Instructional-design theories and models: A new paradigm of instructional theory (Vol. 2). Routledge.

Remes, L. (2001). Yrittäjyyskasvatus pedagogisessa toimintatehtävässä [Entrepreneurship education in pedagogical task]. Kasvatus [Education], 32(4), 368-381.

Rezaei-Zadeh, M., Hogan, M., O'Reilly, J., Cleary, B., \& Murphy, E. (2014). Using interactive management to identify, rank and model entrepreneurial competencies as universities' entrepreneurship curricula. Journal of Entrepreneurship, 23, 57-94. doi:10.1177/0971355713513353

Robinson, R. V. (2018). The Impact of Entrepreneurship Education on Graduate Employability: A Cross Country Comparison. Retrieved from https://sword.cit.ie/busmas/5

Rothwell, A., Herbert, I., \& Rothwell, F. (2008). Self-perceived employability: construction and initial validation of a scale for university students. J. Vocat. Behav, 73, 1-12. doi.10.1016/j.jvb.2007.12.001

Rutherford, C. (2010). Facebook as a source of informal teacher professional development. Retrieved from http://hdl.handle.net/10294/3101

Saad, N., \& Sankaran, S. (2013). The effects of teachers' attitude towards decisions making on teachers' commitment in school: Principals' support as a mediator. Malaysian Journal of Learning and Instruction, 10, 271-294. 
Sánchez, J. C. (2013). The impact of an entrepreneurship education program on entrepreneurial competencies and intention. Journal of small business management, 51(3), 447-465. doi:10.1111/jsbm.12025

Shelton, C. C. C. (2018). Online Teacherpreneurship: Shedding Light on the practice, the Individuals Who Pursue It, and the Impacts They Experience. Arizona State University. Retrieved from https://core.ac.uk/download/pdf/158456852.pdf

Shelton, C. C., \& Archambault, L. M. (2019). Who are online teacherpreneurs and what do they do? A survey of content creators on TeachersPayTeachers. com. Journal of Research on Technology in Education, 51(4), 398-414. doi:10.1080/15391523.2019.1666757

Shelton, C., \& Archambault, L. (2018). Discovering how teachers build virtual relationships and develop as professionals through online teacherpreneurship. Journal of Interactive Learning Research,29(4), 579-602. Retrieved January 23, 2021 from https:/ / www.learntechlib.org/primary/p/178250/

Shelton, C., \& Archambault, L. (2018, March). What Does It Mean to Be an Online Teacherpreneur?: A Qualitative Investigation of Highly Experienced and Successful Authors on Teacher Pay Teachers. In Society for Information Technology $\mathcal{E}$ Teacher Education International Conference (pp. 1724-1728). Association for the Advancement of Computing in Education (AACE). Retrieved January 22, 2021 from https:/ / www.learntechlib.org/primary/p/182761/.

Snell, R., \& Lau, A. (1994). Exploring local competencies salient for expanding small $\begin{array}{lllll}\text { businesses. J. } & \text { Manage. }\end{array}$ https://doi.org/10.1108/02621719410057032

Sofyan, H., \& Efendi, A. (2017, September). Implementation of Teacherpreneurship on Teachers at Vocational High School. In International Conference on Technology and Vocational Teachers (ICTVT 2017). Atlantis Press. doi:10.2991/ictvt-17.2017.39

Spencer, L. M., \& Spencer, S. M. (1993). Competence at work: Models for superior performance . New York: John Wiley \& Sons.

Syam, A. R. (2019). Guru dan Pengembangan Kurikulum Pendidikan Agama Islam di Era Revolusi Industri 4.0. [Teachers and Islamic Education Curriculum Development in the Industrial Revolution Era 4.0]. TADRIS: Jurnal Pendidikan Islam, 14(1), 1-18. doi:10.19105/tjpi.v14i1.2147

Syam, A. R., \& Arifin, S. (2018). Islamic Educational Institution Policies Based on Creative Economic the Asean Era Economic Community. EDUKASI: Jurnal Pendidikan Islam, 6(1), 049-063. Retrieved from https://staimtulungagung.ac.id/ejournal/index.php/EDUKASI/article/view/307

Tao, Y. H., \& Yeh, C. C. R. (2008). Typology of teacher perception toward distance education issues-A study of college information department teachers in Taiwan. Computers $\mathcal{E}$ Education, 50(1), 23-36. doi:10.1016/j.compedu.2006.03.005

Tartavulea, C. V., Albu, C. N., Albu, N., Dieaconescu, R. I., \& Petre, S. (2020). Online Teaching Practices and the Effectiveness of the Educational Process in the Wake of the COVID-19 Pandemic. Amfiteatru Economic, 22(55), 920-936. doi:10.24818/ea/2020/55/920

Teacher Leadership Exploratory Consortium. Teacher Leader Model Standards. (2011). Retrieved

from http://www.teacherleaderstandards.org/downloas/TLS_Brochure_sm.pdf

Torregiani, G. (2020). Teacherpreneur, Gabby, on Keeping an Entrepreneurial Mindset in Challenging Times - BridgeUniverse. Retrieved 13 September 2020, from https://bridge.edu/tefl/blog/teacherpreneur-gabby-keeping-entrepreneurialmindset/ 
Trilling, B., \& Fadel, C. (2009). 21st century skills: Learning for life in our times. John Wiley \& Sons.

Van Dam, K., Schipper, M.,\& Runhaar, P. (2010). Developing a competency-based framework for teachers' entrepreneurial behaviour. Teaching and Teacher Education, 26(4), 965971. doi:10.1016/j.tate.2009.10.038

Wagener, S., Gorgievski, M., \& Rijsdijk, S. (2010). Businessman or host? Individual differences between entrepreneurs and small business owners in the hospitality industry. The Service Industries Journal, 30, 1513-1527. doi:10.1080/02642060802624324

Whitty, G. (2000). Teacher professionalism in new times. Journal of in-service education, 26(2), 281-295. doi:10.1080/13674580000200121

Yuet, F. K. C., Yusof, H., \& Mohamad, S. I. S. (2016). Development and validation of the teacher leadership competency scale. Malaysian Journal of Learning and Instruction, 13(2), 43-69. doi:10.32890/mjli2016.13.2.2 